\title{
USING PEER-RESPONSES AND \\ TEACHER'S WRITTEN FEEDBACK \\ TECHNIQUE THROUGH BLOG IN \\ WRITING II CLASS OF ENGLISH \\ EDUCATION STUDY PROGRAM
}

\author{
Annisa Astrid \\ Universitas Islam Negeri Raden Fatah \\ syahidah0682@yahoo.com
}

\begin{abstract}
This article discusses the result of the research undertaken at PBI UIN Raden Fatah Palembang. The sample of the research was 60 students in Writing II Classes. This study included a guided writing instruction and a questionnaire survey.There were two groups of students involved in this study; control and experimental group. Students in the control group were taught using Peer Response Technique, and the experimental one by using Teacher's written feedback technique. Both groups employed online Blog writing as the means to share feedback. After the treatment done, the students were required to fill the questionnaire items in order to assess their attitude toward the use of Blog in their writing class. The results of the research showed that; (1) there was not a significant difference between students writing achievement before being taught with Teacher's Written Feedback Technique and after being taught with that technique (2) there was a significant difference between students' writing achievement before being taught by using Peer Response Technique and after being taught by using that technique (3) there was significant difference between students' writing achievement who were taught by using Peer Response Technique than
\end{abstract}


those who were taught by using Teachers' Written Feedback and (4) there was positive attitude toward the process of teaching and learning Writing by Using Blog Writing.

Keywords: Peer Response, Teacher's Written Feedback, Blog

\section{INTRODUCTION}

Students of English class usually faces difficulties in writing even to produce a single paragraph. According to Dixon (2005), writing skills is frequently ignored and regarded as the least priority in English classes. There are many reasons due to Dixon's statement. First, the teachers often make writing exercises into homework with no clear purposes. As the result, the teachers often left all the students' writing without checking them at all. Secondly, the textbooks that usually used at schools tend to provide fewer exercises in writing and if the exercises are likely forced to meet the students' need.

Another difficulty that faced by teachers in teaching writing is students' lack of motivation (Wang, 2004). In fact, the students will not actively participated in teaching and learning process if they do not have interest to writing class. In contrary, the students who have high motivation will get involved enthusiastically in all learning processes.

In order to improve students' motivation, the teachers need to have some innovations to design interesting teaching and learning activities in order to foster students to be actively participated (Keh, 1996:95). The innovations related to the selections of appropriate teaching approaches and materials.

There are a number of different approaches to the practice of writing skills both in and outside the classroom. We need to choose between them, deciding whether we want students to focus more on the process of writing than its product, whether we want them to study different genres, and whether we want to encourage creative writing either individually or cooperatively. (Harmer, 2001:257)

The writer's focus is on writing as cooperative activity. Cooperative writing works well with writing process approach. Harmer (2001:258) mentions that the model of process writing is an inter- 
related set of recursive stages which include; drafting, structuring (ordering information, experimenting with arrangements etc.), reviewing (giving feedback, checking context, connections, assessing impact, editing), focusing (that is making sure you are getting the message across you want to get across) and generating ideas and evaluation (assessing the draft and/or subsequent draft).

According to Beason (1993), there are two alternatives of giving feedback; teacher feedback and peer response/peer reviewing. Teacher's written feedback is a feedback giving technique that bridges the teacher to his/ her students. This kind of feedback technique is useful for teachers to clarify the information, giving clues and suggestions and asking the students to do revisions. By having comments from their teacher, it is expected that the students to develop their ideas and to fix their inconsistency in writing. (Furnborough and Truman (2009) and Goldstein (2005)).

However, it is stated that written feedback from the teacher, usually does not give any chance for the students to confirm whenever the feedbacks are not understandable. Furthermore, it usually time consuming that the teacher reluctant to do.

In contrary, the technique of giving feedback from students (peer response technique) is a technique where students give comments on their friends' writing and the one whose his/ her writing is given comments must revise his/her writing based on the comments.. It is such a collaborative writing activity that can improve students' achievement in writing compared to competing and individual writing. (Grabe and Kaplan: 1996:379, Nelson and Murphy, 1993).

As previously mentioned, both of peer response and teachers' written feedback have weaknesses. One of the weaknesses is that both of techniques consume much time. Therefore, since the technology has developed rapidly, the use of computer and online media are alternatives which possibly make the teachers possibly to communicate with their students anytime and anywhere.

Commonly, students write their paragraphs on a piece of paper, then the teacher will give the comment/ feedback also on that paper and whenever the teacher asks the students to do exchanging 
comments, each student must copy their work in order to be distributed to his/her friends. Those activities however are impractical. Therefore by having blog writing as means of learning process it would be much more practical for teaching and learning writing activities, since the students can post their writing task whenever they want, see their published post of their friends and exchanging comment. It is due to William \& Jacobs (2004:232) who state that Blog could create community of learning as means of interaction among students.

Meanwhile, by using blog it would also be easier for the teacher to conduct "writing" teaching and learning activities since by using blog the teacher will not face the limitation of time. By using blog the teaching and learning activities can be done without the need to meet face to face between teacher and students. Moreover, by using blog, the teacher will not feel dizzy by having so much written work of his/her students. The teacher can monitor what his/her students do and can freely give comment on the students' written work wherever and whenever.

Based on the benefits that arised from the implementation of Teacher's Written Feedback (TWF) and Peer Response also the advantage of using blog writing in teaching and learning activities, then the writer did the research on the use of peer response and teacher's written feedback in writing II class of English Education Study Program of UIN Raden Fatah Palembang.

The objectives of the research was to find out: (1) whether by using peer response through blog in teaching writing could improve students' achievement in descriptive paragraph writing, (2) whether by using teacher's written feedback through blog in teaching writing could improve students' achievement in descriptive paragraph writing, (3) whether there is significant difference on students' descriptive paragraph writing achievement between students who are taught by using teacher's written feedback and those by using peer response and (4) students' perceptions on the use of blog in writing class. 


\section{BACKGROUND LITERATURE}

According to Harmer (2001:44), writing has mechanical components like other skills. The components are handwriting, spelling, punctuations, well sentence construction, and composing paragraph and text. Teachers of writing must have realized that students should have mastered all the components in order to get involved in the process of writing

Writing process comprises of pre writing activities, composing and editing (Gebhard, 1980). In teaching writing, the teachers should introduce those three activities before asking their students to write. Otherwise, the students will not be able to produce good paragraph writing.

As previously mentioned above, to overcome the difficulties arise in the complicated process of writing, educators and/or teachers should be creative to present their writing materials with innovative techniques. Since writing is supposed to be collaborative activities in which giving feedback is one of those activities, there are many approaches teachers can used dealing with that. They are teacher's feedback and peer feedback (Beason, 1993). Based on the research entitled Impact of Teacher/Student Conferencing and Teacher Written Feedback on EFL Revision written by Elsa Fernanda Gonzalez, the results shows that: (1) Teacher's written feedback can influence the revision made by the students (2) The revision made by the students focused more on surface aspects than the deep change of the written text and (3) the teachers tend to have interest in the implementation of Teacher-Student Conference, however, some participants tend to have interest on Teacher Written Feedback and some others like both. Below is the short review about teacher's feedback and peer response.

\section{Teacher's Feedback}

Teacher's written feedback is a feedback giving technique that bridges the teacher to his/ her students. This kind of feedback technique is useful for teachers to clarify the information, giving clues and suggestions and asking the students to do revisions. By having comments from their teacher, it is expected 
that the students to develop their ideas and to fix their inconsistency in writing. (Furnborough \& Truman (2009) and Goldstein (2005).

Meanwhile, Goldstein (2005) states that teacher's written feedback does not give space to negotiate meaning; whenever the comments from the teacher are not comprehensible, the students do not have the chance to give clarification. Besides, giving comment is spending time and makes teachers lazy to do that.

\section{Peer Response}

Peer response technique can be implemented in pairs or in small group. In pairs, there are two students who are assigned by the two students themselves or by the teacher will give comment one to another to each written work. Similar to peer response which is implemented in pairs, peer response technique can also be implemented in small groups where each member of the group exchange their written work in order to ask for written comments (Nelson and Murphy, 1993).

There are some benefits of implementing peer response technique. First, this technique is beneficial in making the students more independent in learning processes. Next, as this technique requires the students to cooperate each other by reading and giving comment to their friends' writing can increase their awareness as the writer. It is because when the students have their role as the reader where each of them has to read and try to comprehend the message that try to share from their friend's writing, it will automatically increase their awareness to write comprehensively. Finally, by reading and giving comments to their friends' writing in order to identify the mistakes in terms of paragraph organization, grammar, and writing mechanics it will improve their ability in writing their own paragraph (Forman \& Cazden (1985), Grabe \& Kaplan (1996:379), Allaei and Connor (1990) Mittan (1989) and Moore (1996)).

However there are some critics from experts related to the implementation of peer response technique. They argue that students usually tend to their teachers' response because they 
tend not to believe on their friends' comments. Some experts also emphasize students' disability to evaluate and identify their friends' mistakes in their friends' written work. According to Ashwell (2000), it was found that students only gave comments more on grammar than the content of their friends' writing. This was because students did not have enough knowledge on coherence and cohesion. Besides, according to Holec (1981:3), some teachers of English do not regard the activities of reading and exchanging comments as the important activities in learning processes. It is because of the lack of students' writing skills, and the time.

To come across with the difficulty, especially dealing with the time consuming matter, the use of blog or webblog might become the alternative.

\section{Blog}

Commonly, teenagers like to spend most of their times in front of their computer either to type or to browse from internet. One of their interests is expressing themselves through blog. According to Kurniali (2008), a webblog or blog can be thought of as an online journal that an individual can continuously update with his or her own words, ideas, and thoughts through software that enables one to easily do so. Unlike a standard website, webblog entries are made by typing directly into the browser and with the click of a button instantly published on the internet. All basic document formatting, like spacing, bold, italics, underline, and creating links, requires no knowledge of HTML or FTP (File Transfer Protocol), so that anyone who can type, copy and paste can create and maintain a webblog. However, with a very basic knowledge of HTML, users can extend their ability to customize the layout of their blog and even add pictures to enhance its attractiveness.

Similar to an open journal, the accumulation of writings and other content creates both a record of learning and a resource for others. Furthermore, a webblog is interactive, in the sense that readers can respond to any given entry with a com- 
ment and even threaded discussions can take place depending on the software chosen.

\section{METHODS}

This research employed experimental method. The writer grouped the students into control and experimental pre-test-posttest control group design with matched subject. (Fraenkel \& Wallen, 1990:240-241). In control group, the students were taught by using teacher's written feedback, meanwhile in experimental group the students were taught by using peer response.

The population of the research was the students of second semester of English Education Study Program of UIN Raden Fatah Palembang. The total numbers of students were 120 students which were classified into 4 classes. The data of population are listed in table I

\section{Tabel 1}

Population Data

\begin{tabular}{|c|c|c|}
\hline No & Kelas & Total \\
\hline 1 & PBI 01 & 30 \\
\hline 2 & PBI 02 & 30 \\
\hline 3 & PBI 03 & 30 \\
\hline 4 & PBI 04 & 30 \\
\hline \multicolumn{2}{|c|}{ Total } \\
\hline
\end{tabular}

In order to take the sample, the writer use convinient sample technique (Fraenkel \& Wallen, 1990: 70). Since the writer taught writing in PBI 01 and PBI 02, then the writer took those students in those two clasess into the sample of the study. Then, in order to be sure that the sample has the same ability, the writer did score matching process (Hatch \& Farhady, 1982:117) by determining pairs of students who has similar writing score.

In order to collect the data, the writer used two different kinds of technique; conducting test, and distributing questionnaire. Ac- 
cording to Brown (2004:3) test is a way to assess the ability, knowledge and comprehension on specified section. The test was given before (pretest) and after (posttest) the treatment. The same form of test was given as pretest and posttest where the students were assigned to choose among five descriptive paragraph topics in order to elaborate it intu descriptive paragraph writing.

After the pretest, the students were given treatments. In the control group, the students were taught by using teacher's written feedback. Meanwhile, in the experimental group, the students were treated by using peer response. There were six topics of descriptive paragraph given in each group. In the first meeting of treatment, students of both experimental and control group were asked to make their own account in www.wordpress.com. After they have their own blog account, each of them was asked to add the writer's blog to form a community blog. After that, in the next meeting, the students were introduced in how to write a paragraph by using process approach of writing (generating ideas, drafting, editing and revising). Then, the writer asked them to write descriptive paragraphs based on several topics that were given to them. The students must publish their paragraphs in their blog account.

In the control group, the writer will give comment on students' written work individually then the students must revise their paragraphs and repost them in the blog. Meanwhile, in the experimental group, the writer grouped the students into groups that consist of 4-5 students. Then, the students were asked to give comments on their partners' written work in group. After receiving comments, they have to revise their written work. The process of exchanging and revising the paragraphs must be done in blog.

Then, after the treatments were done, both groups were given posttest to the students in both control and experimental group. Same to the pretest they were asked to choose one of five provided topics and elaborate it into descriptive paragraphs. This posttest is useful to assess whether there was any improvement in both groups of students.

In order to assess the perceptions of students toward the use of blog in writing class, the writer distributed questionnaire to the 
students in both control and experimental group. A ready-made questionnaire from Abu bakar \& Kemboja Ismail (2009), AJTLHE (Asean Journal of Teaching and Learning in Higher education accessed in http//www.ukm.my/jtlhe/, Vol.1, No.1, 45-57 was used as the instrument of data.

After collecting the data, they were analyzed statistically. In order to find out whether there is any improvement in both experiment and control group, paired t-test analysis was used to analyze the data. Then, in order to know whether there is significant difference of students' achievement who were taught by using teacher's written feedback and who were taught by using peer response, independent samples t-test was used to analyze the data. Finally in order to find out the perceptions of students toward the use of blog writing

\section{RESULTS}

In order to find out whether there is significant improvement of students' writing achievement before they were taught and after they were taught by using teacher's written feedback, paired-t-test analysis were used to analyze the data of pretest and posttest. The result of the analysis can be seen in table 2, table 3 and table 4 .

\section{Table 2}

\section{Paired Samples Statistics}

\begin{tabular}{|cc|c|c|c|c|}
\hline & Mean & $\mathrm{N}$ & $\begin{array}{c}\text { Std. De- } \\
\text { viation }\end{array}$ & $\begin{array}{c}\text { Std. Error } \\
\text { Mean }\end{array}$ \\
\hline \multirow{2}{*}{ Pair 1 pretest_control } & 63.8000 & 20 & 4.84062 & 1.08240 \\
& Posttest_control & 65.1500 & 20 & 5.12245 & 1.14541 \\
\hline
\end{tabular}

In the first output listed in Table 2, it can be seen the statistical summary of means scores of pretest and posttest in control group. The table shows that the means score of pretest got before treatment was 63,8 , and the means score of posttest got after the treatment with teacher's written feedback was 65,15 . Therefore, based on the means score of each group, it can be seen that there is improvement. 
Table 3

Paired Samples Correlations

\begin{tabular}{|lc|c|c|c|}
\hline & $\mathrm{N}$ & Correlation & Sig. \\
\hline Pair 1 & $\begin{array}{c}\text { pretest_control \& } \\
\text { Posttest_control }\end{array}$ & 20 & .479 & .033 \\
\hline
\end{tabular}

Table 3 shows the correlation between the scores of pretest and posttest in control group is 0.479 with probability close to 0.05 . In other words, it means that the correlation between the two scores is weak or not significant.

Table 4

Paired Samples Test

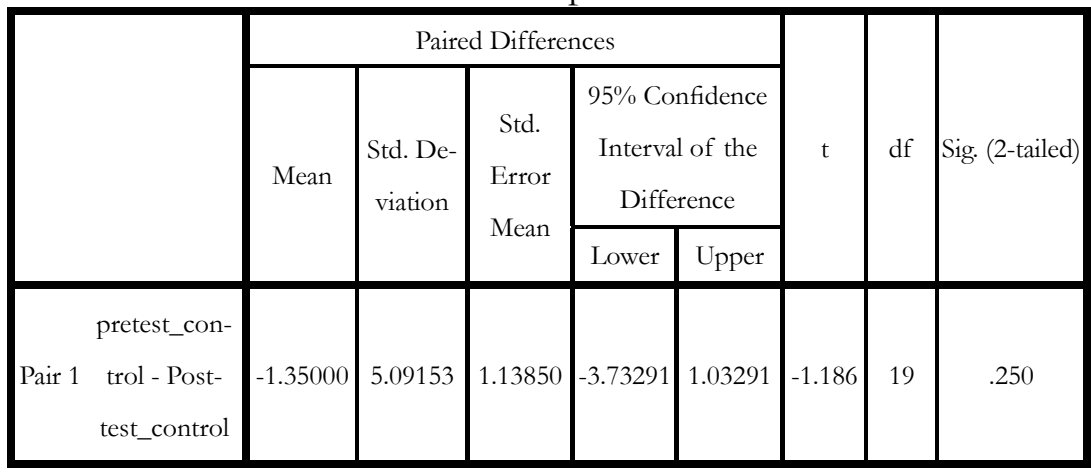

Table 4 shows the result of paired t-test analysis. Based on the probability score; 0.250 which is higher than 0.05 , it means that although there is improvement that shown form the means score difference but this difference is not significant enough to show that the achievement of the scores of students before being treated and after being treated by using teacher's written feedback improved much.

In order to find out whether there is significant improvement between the achievement of students before being treated and after being treated by using peer response technique, paired t-test analysis was used to analyze the scores of pretest and posttest of students 
in experimental group. The results of analysis were shown in table 5 , table 6 and table 7 .

Tabel 5

Paired Samples Statistics

\begin{tabular}{|r|c|c|c|c|}
\hline & Mean & $\mathrm{N}$ & Std. Deviation & $\begin{array}{c}\text { Std. Error } \\
\text { Mean }\end{array}$ \\
\hline Pair 1 $\begin{array}{c}\text { petest_ } \\
\text { experiment }\end{array}$ & 63.8000 & 20 & 4.84062 & 1.08240 \\
$\begin{array}{r}\text { posttest_- } \\
\text { experiment }\end{array}$ & 71.3500 & 20 & 4.77135 & 1.06691 \\
\hline
\end{tabular}

In the first output listed in Table 5, it can be seen the statistical summary of means scores of pretest and posttest in control group. The table shows that the means score of pretest got before treatment was 63,8 , and the means score of posttest got after the treatment with teacher's written feedback was 71.35. Therefore, based on the means score of each group, it can be seen that there is improvement.

Table 6

Paired Samples Correlations

\begin{tabular}{|c|c|c|c|}
\hline & $\mathrm{N}$ & Correlation & Sig. \\
\hline Pair 1 $\begin{array}{c}\text { pretest_experiment \& } \\
\text { posttest_experiment }\end{array}$ & 20 & .883 & .000 \\
\hline
\end{tabular}

Table 6 shows the correlation between the scores of pretest and posttest in control group is 0.000 with probability lower than 0.05. In other words, it means that the correlation between the two scores is highly significant. 
Table 7

Paired Samples Test

\begin{tabular}{|c|c|c|c|c|c|c|c|c|}
\hline & \multicolumn{5}{|c|}{ Paired Differences } & \multirow{3}{*}{$\mathrm{t}$} & \multirow{3}{*}{ df } & \multirow{3}{*}{$\begin{array}{c}\text { Sig. } \\
\text { (2-tailed) }\end{array}$} \\
\hline & \multirow[t]{2}{*}{ Mean } & \multirow[t]{2}{*}{$\begin{array}{l}\text { Std. De- } \\
\text { viation }\end{array}$} & \multirow[t]{2}{*}{$\begin{array}{c}\text { Std. } \\
\text { Error } \\
\text { Mean }\end{array}$} & \multicolumn{2}{|c|}{$\begin{array}{l}95 \% \text { Confidence } \\
\text { Interval of the Dif } \\
\text { ference }\end{array}$} & & & \\
\hline & & & & Lower & Upper & & & \\
\hline Pair $1 \begin{array}{l}\text { pretest_ex- } \\
\text { periment - }\end{array}$ & -7.55000 & 2.32775 & .52050 & -8.63942 & -6.46058 & -14.505 & 19 & .000 \\
\hline $\begin{array}{c}\text { posttest_ } \\
\text { experiment }\end{array}$ & & & & & & & & \\
\hline
\end{tabular}

Table 4 shows the result of paired t-test analysis. Based on the probability score; 0.000 which is lower than 0.05 , it means that although there is improvement that shown form the means score difference and its difference shows that the achievement of the scores of students before being treated and after being treated by using Peer Response Technique improved significantly

In order to find out whether there is significant improvement between the achievement of students after being treated by using Teacher's Written Feedback and after being treated by using peer response technique, independent samples t-test analysis was used to analyze the scores of posttest of students in control and experimental group. The results of analysis were shown in table 8 , table 9 and table 10.

\section{T-Test}

Table 8

Group Statistics

\begin{tabular}{|c|c|c|c|c|c|}
\hline & Group & $\mathrm{N}$ & Mean & Std. Deviation & Std. Error Mean \\
\hline \multirow{2}{*}{ Posttest } & Control & 20 & 65.1500 & 5.12245 & 1.14541 \\
\hline & experiment & 20 & 71.3500 & 4.77135 & 1.06691 \\
\hline
\end{tabular}


In the first output listed in Table 8, it can be seen the statistical summary of means scores of pretest and posttest in control group. The table shows that the means score of posttest got after the treatment by using Teacher's Written Feedback was 6.15, and the means score of posttest got after the treatment with Peer Response was 71.35. Therefore, based on the means score of each group, it can be seen that there is improvement.

\section{Table 9}

\section{Independent Samples Test}

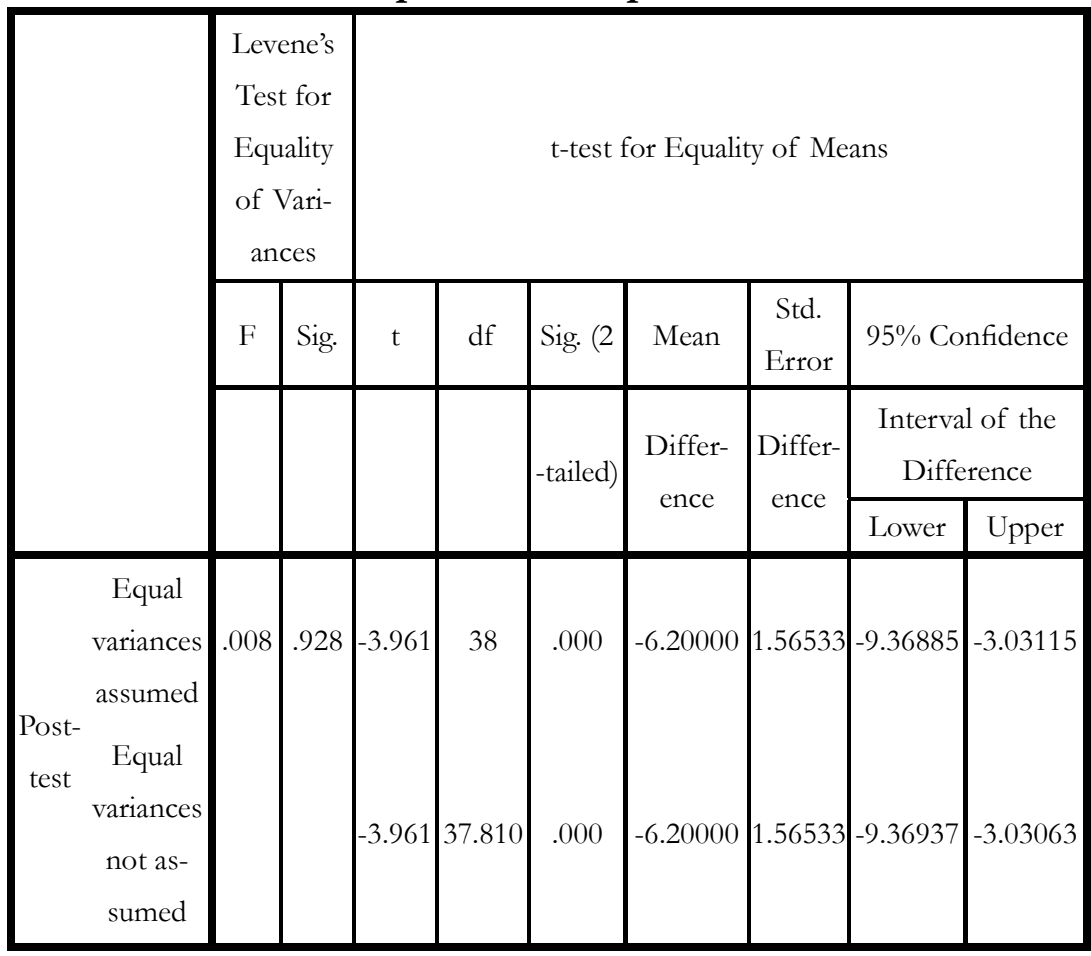

Table 9 shows the result of independent samples t-test analysis. Based on the significancy F score; 0.928 which is higher than 0.05 , it means that both variance in both groups; control and experimental are assumed equal. Moreover, based on significancy 2 tailed score 0.000 which is lower than 0.05 , it means that there is significant difference between posttest scores of control group and posttest scores of experimental grouped. In other words, the achievement of students in writing descriptive paragraph improved more signifi- 
cantly when they were being taught by Peer Response Technique than by Teacher's Written Feedback

Furthermore, the results of the analysis of each item in the questionnaire in order to assess students' perceptions of the use of blog in their writing class can be seen in table 10 .

TABEL 10

Results of Questionnaire Analysis

\begin{tabular}{|c|c|c|c|c|c|c|c|c|}
\hline \multirow{2}{*}{ Item } & $\begin{array}{c}\text { Strongly } \\
\text { Agree } \\
\text { (SA) }\end{array}$ & \multicolumn{2}{c|}{$\begin{array}{c}\text { Agree } \\
\text { (A) }\end{array}$} & \multicolumn{2}{c|}{$\begin{array}{c}\text { Disagree } \\
\text { (D) }\end{array}$} & \multicolumn{2}{c|}{$\begin{array}{c}\text { Strongly Dis- } \\
\text { agree } \\
\text { (SD) }\end{array}$} \\
\cline { 2 - 10 } & Total & $\%$ & Total & $\%$ & Total & \% & Total & \% \\
\hline 1 & 10 & 17 & 40 & 67 & 8 & 13 & 2 & 3.3 \\
\hline 2 & 5 & 8.3 & 45 & 75 & 5 & 8.3 & 5 & 8.3 \\
\hline 3 & 2 & 3.3 & 48 & 80 & 10 & 17 & 0 & 0 \\
\hline 4 & 8 & 13 & 42 & 70 & 10 & 17 & 0 & 0 \\
\hline 5 & 5 & 8.3 & 35 & 58.3 & 10 & 17 & 10 & 17 \\
\hline 6 & 10 & 17 & 10 & 17 & 35 & 58.3 & 5 & 8.3 \\
\hline 7 & 20 & 33,3 & 20 & 33,3 & 20 & 33,3 & 0 & 0 \\
\hline 8 & 5 & 8.3 & 45 & 75 & 10 & 17 & 0 & 0 \\
\hline 9 & 5 & 8.3 & 40 & 67 & 15 & 25 & 0 & 0 \\
\hline 10 & 0 & 0 & 50 & 83,3 & 5 & 8,3 & 5 & 8,3 \\
\hline 11 & 6 & 10 & 30 & 50 & 10 & 17 & 4 & 6,7 \\
\hline 12 & 10 & 17 & 40 & 67 & 10 & 17 & 0 & 0 \\
\hline 13 & 5 & 8,3 & 50 & 83,3 & 5 & 8,3 & 0 & 0 \\
\hline 14 & 10 & 17 & 45 & 75 & 5 & 8,3 & 0 & 0 \\
\hline 15 & 20 & 33,3 & 45 & 75 & 4 & 6,7 & 1 & 1,7 \\
\hline 16 & 20 & 33,3 & 20 & 33,3 & 16 & 26,7 & 4 & 6,7 \\
\hline
\end{tabular}




\begin{tabular}{|c|c|c|c|c|c|c|c|c|}
\hline 17 & 0 & 0 & 45 & 75 & 15 & 25 & 0 & 0 \\
\hline 18 & 0 & 0 & 48 & 80 & 10 & 17 & 2 & 3,3 \\
\hline 19 & 0 & 0 & 30 & 50 & 30 & 50 & 0 & 0 \\
\hline 20 & 10 & 17 & 45 & 75 & 5 & 8,3 & 0 & 0 \\
\hline 21 & 20 & 33,3 & 35 & 58,3 & 5 & 8,3 & 0 & 0 \\
\hline 22 & 30 & 50 & 10 & 17 & 20 & 33,3 & 0 & 0 \\
\hline 23 & 0 & 0 & 30 & 50 & 30 & 50 & 0 & 0 \\
\hline 24 & 8 & 13,33 & 48 & 80 & 4 & 6,7 & 0 & 0 \\
\hline 25 & 8 & 13,33 & 40 & 66,7 & 10 & 17 & 2 & 3,3 \\
\hline
\end{tabular}

Note: Items in the questionnaire are as follows

1. A blog is a useful tool for you to share your writing / ideas with others in the cyberspace/world

2. Posting my articles on my blogs is a good idea

3. I agree it is a good idea to use blogs for writing in an English class

4. I learn to write better when writing on blogs.

5. I check my work carefully before posting it online.

6. I don't check my work carefully when I write on paper.

7. I check my grammar carefully before posting it.

8. I am not shy to share my work in cyberspace/world

9. I feel that my writing is better when writing on my blogs than writing on paper in class.

10. I can express my idea better when writing on my blogs than on paper

11. I feel more confident with my writing ability when writing on my blogs than on paper

12. I feel that I can write longer when writing on my blog than on paper

13. I feel no pressure when writing on my blog because I have more time to write

14. I like to read the comments from friends and teachers on my 
blogs because they are useful for me in improving my writing ability.

15. Overall, I feel that I have improved my writing in English in the areas of grammar, structure, and vocabulary.

16. Blogging should be used as part of writing activities in class because of its benefits.

17. I have improve my writing skills since I began blogging

18. I will continue blogging outside the class

19. I am not ashamed to express my thoughts on my blog

20. Blogging should be a part of the writing activities in classes

21. I like my friends to read my writing on my blog

22. I write effectively when blogging

23. can write effectively although my English is limited

24. I believe that blogging is good writing practice

25. I feel that writing on my blog is fun

Based on the item analysis it was found out that students have positive attitude toward the use of blog in their writing class. Commonly, most of students who determined their opinion in the questionnaire have been familiar with internet, but some of them were not familiar with blog. Among 60 students who returned the questionnaires, 30 students $(50 \%)$ have been using internet since 1 till 3 years ago, 12 students $(20 \%)$ since 4 years ago and 7 students (12\%) have used internet for more than 5 years

Furthermore, 40 students $(67 \%)$ has heard about blog but only know a little on how to work in it, meanwhile around 10 students $(17 \%)$ have heard about blog but have not got the sense on the purpose of using blog. However, because the learning processes were done by employing blog, then the students were encouraged to learn more about blog.

Among all students, 45 of them $(75 \%)$ stated that it is easy to design their own blog and only 10 of them (17\%) who said that designing blog is difficult. However, every students participated in writing II class had fulfilled the requirement to have designed their own blog.

48 students $(80 \%)$ mentioned that writing in blog is such an ex- 
citing activity and it is emphasized from the opinion of 48 students $(80 \%)$ who were enthusiastic and stated that they will continue the writing activities in blog after the classes were fulfilled.

Most of students felt that the use of blog as the means of learning process is such a good idea. The students felt the benefits of the activities done. When they wrote in blog, they (50 students, $83 \%$ ) felt that they could write better through blog because 40 of them $(67 \%)$ were much more careful in checking their writing before they published it. Only 20 students $(33,3 \%)$ who stated that were just ignore what they have written and just published it without further checking. The better results of students' writing were probably because most students were realize that when they wrote on online media, then everyone can read what they have published then automatically will increase students' efforts to write their best.

Furthermore, when they wrote in their own blog, 40 students $(67 \%)$ felt that they could write effectively even that they have limited ability in (30 people, 50\%). 50 students (83.3\%) felt that they could write longer in the online blog than just on a piece of paper. This was because they had much more space of time to write than if they had to write in their class with a limited time. The students realized that the situation really supports their mood in writing. It was proved that their writing ability tend to improve in the learning processes.

In giving comment session 55 students $(92 \%)$ believed that by reading their friends' comment will improve the quality of their writing. Giving comment session was not only helpful in improving students' writing ability but also can increase their confidence while giving comment as expected to improve their friend' written work.

Compared to writing on a piece of paper, most of students (45 students, 75\%) mentioned that they wrote better in blog. Around 48 students $(80 \%)$ said that it was much fun when they were assigned to write in their own blog, because they were freely to expressed themselves, they could even posted some pictures related to the topic of writing they chose that made their writing much more interesting and informative. Those activities cannot be done whenever they had to write on a piece of paper in their class. By having those ac- 
tivities, 36 students $(60 \%)$ mentioned that they became much more confident in writing.

\section{CONCLUSION}

Based on the results of the data above, it can be concluded that:1) there was not a significant difference between students writing achievement before being taught with Teacher's Written Feedback Technique and after being taught with that technique (2) there was a significant difference between students' writing achievement before being taught by using Peer Response Technique and after being taught by using that technique (3)there was significant difference between students' writing achievement who were taught by using Peer Response Technique than those who were taught by using Teachers' Written Feedback and (4) there was positive attitude toward the process of teaching and learning Writing by Using Blog Writing. 


\section{REFERENCES}

Allaei, S. and Connor, U. (1990). Exploring the dynamics of crosscultural collaboration in writing classrooms. The Writing instruction. 10(1): 19-28

Ashwell, T. (2000). Patterns of teacher response to student writing in a multipledraft composition classroom: Is content feedback followed by form feedback the best method? Journal of Second Language Writing. 9(3): 227-257.

Beason, L. (1993). Feedback and revision in writing across the curriculum classes. Research in the Teaching of English, 27(4), 395422.

Dixon, N. 2005. Why put writing last? - Integrating the Productive Skills in General English Classes. Paper presented in LIA International Conference 2005, Jakarta, March 22-24.

Forman, E.A. and Cazden, C.B. (1985). Exploring Vygotskian perspective in education. In J. V. Wertsch (ed.). The cognitive value of peer interactions. (pp. 332-347).

Furnborough, C., \& Truman, M. (2009). Adult beginner distance language learner perceptions and use of assignment feedback, Distance Education, 30, 399-418.

Gebhard, R. (1980). Teamwork and feedback broadening the base of collaborative Writing. College Coposition and Communication. 42: 69-74.

Grabe, W. and Kaplan, R.B. (1996). Theory \& Practice of Writing. London: Pearson Education. 
Harmer, J. (2001). The practice of English language teaching (3rd ed.). Essex: Longman.

Hatch, E \& Hossein Farhady. (1982). Research Design and Statitistics for Applied Linguistics. Rowley, Massachusetts: Newbury House Publishers.

Holec, H. 1981. Autonomy and foreign language learning. Oxford: Pergamon.

Keh, C.L. (1996). Feedback in the writing process. In T. Hedge and W. Norman (eds.). Power, pedagogy and practice (pp. 294-306). Oxford: Oxford University Press.

Kurniali, Sartika. 2008. Tip-Trik Pilihan Blogger. Jakarta. PT Elex Media Computindo.

Mittan, R. (1989). The peer review process: harnessing students' communicative power. In D.M. Johnson and D.H. Roen (eds.), Richness in writing (pp. 207-219). New York: Longman.

Moore, H. (1996). Telling what is real: Competing views in assessing English as a second language development. Linguistics and Education. 8: 189-228.

Nelson, G. and Murphy, J. (1993). Peer response groups: Do L2 writers use peer comments in revising their drafts? TESOL Quarterly. 27: 135-142.

Wallen, N.E. (1991). Educational Research: A Guide to the Process.USA: McGraw Hill Inc.

Wang, Y. 2004. English magazines = motivation + Improved EFL writing skill. English Teaching Forum, 43(3): 18-22 
Hidayah Nor \& Nur Alfa Rahmah 